Journal of Language Teaching and Learning, Linguistics and Literature

\title{
Nature's Involvement in Women's Self-Completion: An Eco-feminist and Psychoanalytic Criticism on Selected Indonesian Folktales
}

\author{
Santa Maya Pramusita ${ }^{1}$; Antonius Wisnu Yoga Windharto ${ }^{2}$ \\ Santa.pramusita@uph.edu \\ Antoniusyo91@gmail.com \\ 1Universitas Pelita Harapan, Tangerang, Indonesia \\ 2Universitas Sanata Dharma, Yogyakarta, Indonesia
}

Received: 17 November 2020 Accepted: 24 November 2020

DOI: $10.24256 /$ ideas.v8i2.1683

\begin{abstract}
Human beings unavoidably have an innate need to conjugate with other living creatures such as plants and animals. This fundamentally indicates that human builds a sense of connection to nature, that even sometimes they involve nature as one of the symbols in their process of self-completion. They make use of nature in such a way to define themselves as if they possess competencies in accordance with the titles. This paper seeks to find out the depiction of nature in several Indonesian folktales and to disclose how women in those tales are naturally connected with nature and engage it in their self-completion process. Psychological and feminist eco-critical approaches are utilized to answer those problem formulations. Meanwhile, the reason why the researchers only analyze female characters is that they are told in the tales to have an intimate relationship with nature and become the representation of 'Mother Earth'. The analysis results show that nature in the selected folktales is depicted as pretty chummy to oppressed women. They are so connected that even those women establish nature as their medium to reveal their self-concept as strong, consistent, and honest women
\end{abstract}

Keywords: Feminist ecocriticism, Indonesian Folktales, Psychoanalysis, Self-completion.

\section{Introduction}

Biophilia hypothesis proposed by Wilson (1984) postulate human's tendency to keep close with the nature around them. This phenomena have been detected since the ancient times where Egyptian, Persian, and medieval Chinese settlements were all equipped with spacious gardens indicating that they strived to always be connected with nature. In more recent times, Biophilia hypohesis is strengthened by the presumption that exposure to nature preserves psychological well-being, decreases pressure, and increases physical well-being (Ulrich, 1993). As the result, natural environments such as parks, zoo, beaches, and other landscapes are massively visited by the crowd. Human's innate need to be one with nature can also be regarded on their excitement when making contact or observing other living creatures. Nature, hence, is indeed a physical world that human being can be weak without. 
Despite having a pro-environmental attitude, we should not forget the facts that mankind inherently develops greedy behavior as well. Taflinger (1996) defines greed as "an extreme or excessive desire for resources, especially for property such as money, real estate, or other symbols of wealth" (p.1). As society tends to correlate success with material things such as house, cars, salary, fancy clothes, and luxury travel, human satisfaction seems to rarely stop by. They always want to possess more things beyond their basic needs, and this unsustainable consumption have definitely profound implications on environments. According to Pandey (2020), "since industrial revolution in 1850, the energy use has increased 25 times to feed human consumption, freshwater use has also increased 10 times and land under cultivation and habitation has expanded threefold. In the process, human have destroyed 30\% of tropical forests and wiped out $60 \%$ of mammals, birds, fish, and reptiles" (p.1). This ecological destruction is undoubtedly the most consequential effect of human greed.

Sadly, the degradation nowadays has plundered a lot of countries, including Indonesia. As a tropical archipelago, Indonesia is endowed with an abundance of natural resources such as forest, fertile soil, gold, petroleum, silver, coal, tin, copper, timber, nickel, and natural gas. While mining sector has carried economic benefits to the country, the greed has been exploiting the biosphere in a way that increase the risk of severe damage. People are more triggered to conquer nature for the sake of wealth rather than to nurture it. In consequence, Indonesian natural resources are overused and undervalued, which then leading to ecological imbalance.

Concerning this sorrowful condition, Indonesian people had actually been warned since long time ago. A lot of admonitions are implied in Indonesian folktales and myths that tell the story about the natural disaster caused by human's greediness. The use of literature element here is nothing but to open people's mind on conserving nature. Following Bruner's notion (1991), narrative text like folktales "operates as an instrument of mind in the construction or reality" (p.6). It means that tales assist human to figure out the real world, in this case, the importance of saving natural environment and the awareness of appreciating the values of nature. Through the symbol, metaphor, and style, literature provides contextual representation of human's action without judging them directly. Eco-critic reading is thus suitable to discuss tales raising ecological issues.

The focus of this paper is on four selected Indonesian folktales and legends from different regions in Indonesia. They are Malin Kundang from West Sumatera, LegendaDanau Toba from North Sumatera, LegendaBanyuwangi from East Java, and LegendaBatuMenangis from Kalimantan. The researchers choose these stories because they set nature as an important constituent of the plots. It is not merely a background, but it is developed into substantial aspect which pretty much influencing the storyline. These stories also have similarities that their main characters are women and that some antagonist characters are punished into nature-related stuffs, while the protagonist characters unite with the nature at the end of the stories.In other words, the researchers decide to use these folktales because it obviouslyattempts to reassure the readers on the inseparable connection among human and nature.

The objective of this study alone is to investigate how nature is depicted in the selected Indonesian folktales, like whether it is something mysterious, destructive, beautiful, or powerful. The portrayal of some women characters will also be entangled as the researchers found them to be deeply connected with nature in the folktales. To enrich the discussion, the researchers will elaborate how nature is set by some women 
characters to be the part of their self-completion.

Self-completion is generally a psychological concept proposes that "people define themselves as musicians, athletes, etc. by use of indicators of attainment in those activity realms, such as possessing a prestige job, having extensive education, or whatever is recognized by others as indicating progress toward completing the self-definition" (Wicklund\& Gollwitzer, 1981, p.89). To put it another way, self-completion refers to someone's way of using or searching of symbols of achievement toprecisely state themselves as resolved in self-identification process and to show their attainment to others. Figuring out the women characters' process of self-completion will be very relevant to this study because all women characters in the selected folktales are likely to implicate nature in their process of defining self. Related analysis hence allows readers to comprehend more the connection among women and nature. The results of this research may contribute on the study regarding Indonesian folktales as well as environmental and cultural issues.

Similar studies have been previously conducted by Subanti (2018) who examines human an environmental conflict in the story of The Mermaid using Feminist and Ecocritical perspective. His analysis reveals how natural exploitation triggers environmental conflict between mankind and other living creatures as reflected much through dialogues and characters' perspectives in the story. He also focuses on gender issue in which the main character is built to be the passive woman who cannot avoid male's authority and marital bind. Another related study is done by Putri (2018) who uses feminist approach to criticize patriarchal society and the oppression of women characters in several Indonesian folktales. The results of her analysis indicate that the chosen folktales describe women characters mostly as submissive characters who are oppressed by people in power and sold for their beauty. Considering the background, the study was done based on these problem formulations: (1) How nature and women are depicted in the four selected folktales? (2) How nature plays a role in the process of self-completion lived by the women characters in the stories?

Ecocriticism is the study of relationship between nature and literature, particularly the cultural artefacts language and literature (Glotfelty, 1996). It concerns on how ecological issues and cultural issues related to physical environment are presented in the literary texts. Also, it seeks to examine human's attitude and reaction toward nature and environmental aspects. Mambrol (2016) conveys that ecocriticism "has gained a lot of attention during recent years due to higher social emphasis on environmental destruction and increased technology" (p.1).In line with this, Dewi (2016) elaborates that ecocriticsm focuses on how literary texts describe nature which is now slowly destroyed by the global environmental crisis, and the efforts to practically and theoretically resolve the crisis.

The fundamental principle of ecocriticism is that human being is connected to the physical world, by way of both affecting and being affected by it. They may positively affect nature by doing reforestation, recycling,cleaning up the environment, creating environmental regulations, andbuilding green and open space. Yet, they may also influence nature in negative ways through pollution, deforestation, overfishing, overpopulation, and over-exploitation which then leading to lack of food supply, decrease in quality of public health and increased risk of natural disasters. Literary texts have long represented such degraded ecosystem and other environmental issues as a stern warning; therefore, ecocriticism appears. 
Eco-centered reading focuses on the outer part or the setting of story rather than the inner partssuch as the characters or author's psychology. It generally deals with energy, entropy (kind of negative energy within systems which is likely to ruin and disorganize), and symbiosis (literary means 'living together', denoting mutually sustaining, co-existing systems) (Barry, 2009). There are various natural imaginations in literature; and environmental criticism is a representation of the most radical one compared to those that praise the beauty of nature as in romantic poetry or naturalistic realist/deterministic novels resisting the cruelty of nature to people (Clark, 2010).

As natural damage becomes burning issue in the current era, feminist movement then emerges with the new branch called ecofeminism. It mainly talks about the relationship between women and nature, especially in terms of helplessness and unfair treatment of both. Ecofeminism perceives environmental damage as directly proportional to cases of subordination of women, hence it sees "women and nature as property, seeing men as the curators of culture and women as the curators of nature, and how men dominate women and humans dominate nature" (Zein\&Setiawan, 2017, p.1). It is a common knowledge that our society tends to offer an uttermost priority to men and to some extent restricts women's rights as well. Many people even still consider women as powerless, intuitive, submissive, and dependent being, who are supposed to work inside home, taking care of children, serving husband, etc. While feminists reject this patriarchal system, ecocriticism rejects the notion that everything is socially and/or linguistically constructed (Barry, 2009, p.255). The two literary movements seem having a tendency to reject some terms that already exist before. This automatically impacts the view of feminist ecocriticism in a way that it must rethinkperhaps even deconstruct-some of its undiscussed assumptions about identity, politics and the relations between the two if it is to continue as a viable political and social movement (Sandilands, 1997).

Apart from dealing with issues of domination toward women and environment, eco-feminism is also closely related to the issue of historical relationship between women and nature. In the Rigveda, the term 'Mother Earth' is the antonym of 'Father Sky' where earth and sky are often addressed as a couple. The earth is called Mother because it is the place where humans are born and where their bodies will lie at the end of life. Earth indeed gives life to all creatures in this world. The food, drink, and everything that human consumes comes from earth, particularly its plants, animals, and water. This means that earth has a role as the one who gives birth to, grows, and maintains all creatures. Supporting this, Torres (as cited by Finzer, 2015) appeals to women's essential link to Mother Earth in order to motivate them to cultivate kitchen gardens, maintain a clean homestead, and encourage their male partners in conservation-minded agricultural practices. The analogy between nature and women also can be seen in sense that the nature takes care of human and the things, and that is same with women who take care of the household.

In this study, the researchers also involved psychoanalytic criticism to reveal the personality of the women characters and to enrich the discussions. Psychoanalysis criticism attempts to find the motive behind the action of human proposed by Sigmund Freud (1856-1939). The main concept of psychoanalysis by Freud relies on the level of consciousness in human mind consisting of the consciousness, the conscience, and the unconscious ones. Freud then developed those levels of personality into Id, Ego, and Superego. Id is a person's 'real' personality that exists from he was born and is influenced by desire, need, and instinct. Meanwhile, ego refers to the action that humans 
do to fulfil the id. Ego works based on the principle of reality, or in other words, it realizes the id in a realistic and logical way. The last system, superego, is the embodiment of values given from parents and society to a person (Barry, 2009). Similarly, Lacan (1901-1981) also correlated psychoanalysis theory with unconsciousness mind, but he argued that unconsciousness was structured like a language as in the metaphor and metonymy. Metaphor usually happens when an object is used to symbolize unrelated object while metonymy refers to the replacement of the name of the object with the name of something else which is closely related. Based on those things, Lacan concluded that human unconscious mind resembles metaphor and metonymy in a way that it uses different things to represent other objects.

One of the theories under psychological field that can be a basis for analysis is symbolic self-completion theory. It argues that people try to obtain and expose symbols which are very much related to what they assume to be their ideal selves. Individuals are usually driven to show off symbols of achievement to define themselves when they are lackingof substantial indicators of attainment in self-defining area (Harmon-Jones et al., 2009). Meanwhile, one's self is defined by the reaction of people around him, specifically through his behavior, verbal statement, or potential signals. When his 'symbols' are noticed by others, he will automatically feel the sense of completeness. That is why person demands others' acknowledgement to gain a desired self-definition (Wicklund\& Gollwitzer, 1981). It is, nevertheless, not a duty for people to validate one's goals because recognition is all that is needed. When one's symbols are socially acknowledged, he will certainly have enough. This argument is deeply in line with Maslow's theory of human motivation where he differentiates five levels of needs; psychological, security, social, and esteem needs. Psychological needs refer to the most fundamental hierarchy of human needs to live such as food, water, oxygen, clothes, residences, and so on. Security needs include safety and protection from the dangers and anxious feelings. Social needs are related to all forms of interaction with other people. Esteem needs deals with social recognition, achievement, personal worth, and self-esteem. Human beings definitely "have a need to accomplish things and then have their efforts recognized ... [because] satisfying this need and gaining acceptance and esteem helps people become more confident" (Mawere et al., n.d, p.6). The last and the highest hierarchy of needs according to Maslow is self-actualizing need that concerns with one's personal growth, self-awareness, and the development of his true potential. Esteem need is the need which supports symbolic self-completion theory that human needs social recognition to some extent, and in order to meet it, they uses certain symbols representing themselves. The symbols alone are divided into three groups, being based on: "(a) The background experience or training requisite to the activity; (b) occupying a position or status that furthers the relevant activities; or (c) performance of the act itself" (Wicklund, 1981, p.92). In this paper, the focus relies more on the performance or action taken by the women characters in the selected folktales.

\section{Method}

To achieve the purpose of this study related to analyzing the involvement of nature in women characters' process of self-completion in several Indonesian folktales, the 
researchers utilize descriptive qualitative research design. This design is chosen because it allows the researchers to provide rich description and interpretation of certain phenomena. As elaborated by Nassaji (2015), descriptive qualitative research design often involves rich and detail collection of data to get deeper comprehension, as well as "inductive exploration of the data to identify recurring themes, patterns, or concepts, and then describing and interpreting those categories" (p.130).

The data analyzed are four selected texts of Indonesian folktales which are drawn from online resources (Malin Kundang from West Sumatera, Legenda Danau Toba from North Sumatera, Legenda Banyuwangi from East Java, and Legenda Batu Menangis from Kalimantan). The stories are chosen because its plots depict the connection among nature and human in a very obvious way. It also has similarities that there are some women characters in the stories who undergo the process of self-completion and establish nature as one of their symbols.

There are some steps that the researchers take in data analysis. Firstly, the researchers read the whole stories for several times. After getting the main points of the tales, the researchers re-read it and shift the focus on the main women characters. Thirdly, all evidences related to the characters are identified, sorted and classified. The next step is to describe and interpret the data to reveal the nature's involvement in the women characters' process of self-completion. The interpretation is based on eco-feminist and psychoanalytic perspectives.

\section{Results}

The analysis of four selected folktales result in some emergent interpretations which will be analyzed under this sub-section:

1) The Analysis of 'Malin Kundang.'

The tales build the figure of Malin's mother as the loving one. Her love to Malin was deeply unconditional that she was willing to do anything for the sake of Malin's happiness. Her great love to Malin were also reflected in the data below:

Mother, what if I sail overseas?" asked Malin Kundang one day to his mother. Her mother didn't agree but Malin Kundang had made up his mind. "Mother, if I stay here, I'll always be a poor man. I want to be a successful person," urged Malin Kundang. His mother wiped her tears, "If you really want to go, I can't stop you. I could only pray to God for you to gain success in life," said his mother wisely. (D1_MK)

The data show how Malin's mother loved her son so much that she was willing to suffer and to live all alone in her old age, as long as her son got happiness. It was not easy for sure and it was something she actually did not favor, but her love to Malin is greater than her fear. Furthermore, in the end of story, she did not immediately curse Malin, but she gave him a chance to change his behavior, as depicted below:

Malin Kundang's mother take a step back, "Malin...You don't recognize me? I'm your mother!" she said sadly. Malin Kundang's face was as cold as ice. "Guard, take this old women out of here," Malin Kundang ordered his bodyguard. "Give her some money so she won't disturb me again!" Malin Kundang's mother cried as she was dragged by the bodyguard, "Malin... my son. Why do you treat your own mother like this?"(D2_MK) 
This indicates how she still loved Malin despite his behavior and how she hoped Malin to back behaving like old times. The way she asked reflective question, "Malin... my son. Why do you treat your own mother like this?" obviously implies her deepest desire for Malin to reflect and realize his evil behavior. The mother was also told to have connection with nature, seen on how she cursed Malin:

In the quiet sea, suddenly the wind blew so hard and a thunderstorm came. Malin Kundang's huge ship was wrecked. He was thrown by the wave out of his ship, and fell on a small island. Suddenly, his whole body turned into stone. He was punished for not admitting his own mother(D3_MK)

The sea and the wind that turned into a storm was a symbol of how nature understoodMalin's mother sad and angry feelings. This incident also signifies the closeness of the two, because if Malin's mother was not close to nature, it would not assist her expressing her disappointment.

2)The Analysis of 'The Legend of Lake Toba'

The tale of 'The Legend of Lake Toba' portrayed woman as pretty and enchanting as seen in these data:

"Who are you, O beautiful lady? Where did you come from? Why are you in my house?" asked the astonished farmer."I was your carp and the gold coins on the table are the embodiment of my scales." Replied the beautiful woman."Will you be my wife $O$ beautiful lady?" Asked the young man shyly.(D4_LT)

The way Mr. Toba flattered her and asked her to be his wife the first time they met indicated how beautiful she was that he was immediatelyhooked. Moreover, the woman was also seen to have a wife material since she could cook well and always brought her husband food to work:

They had a son named Samosir. After the age of 6 years old, he turned into a very naughty boy and difficult to advised. His mother often told him to deliver rice to his father in the fields, but Samosir always rejected. (D5_LT)

As she was the fish incarnation, she was closely attached to nature as depicted below:

"Your father broke his oath by told the origin of your mother. Now I must return to my origin."At that moment the sky became dark, lightning followed by heavy rain. Samosir and her mother disappeared without any trace, while at the former place they stand spurted heavy water. Not long after that, the place flooded to form a lake. While the father could not save himself, he died, sinking into the lake.(D6_LT)

The way nature reacted here resembled the way nature in the tale of 'Malin Kundang' retaliated. It expressed the anger and disappointment of the women's characters and condemned those who acted arbitrarily. In addition, the incident above a bit much denoted that nature in this tale was considered as powerful entity which could eliminate life. 


\section{3) The Analysis of 'The Legend of Banyuwangi'}

In line with 'The Legend of Lake Toba', the tale of 'The Legend of Banyuwangi' also delineated the main women character as a very beautiful woman:

A young and beautiful girl opened the door. She was very beautiful. Patih Sidapaksa fell in love at the first sight."How can I help you Sir?" asked the girl."I...I... am looking for a young deer", Patih Sidapaksa was speechless.(D7_LB)

It can be noticed from the narrator explanation and the reaction of PatihSidapaksa when seeing her. He fell in love and lost his wordsat the moment Sri Tanjung opened the door. Besides, Sri Tanjung was depicted as a very honest and faithful woman, as indicated on these data:

She did not accept the proposal. She loved Patih Sidapaksa and she already promised to wait for him. The King was angry and put her in the jail.(D8_LB)

She kept her love for Sidapaksa firmly, even though she knew it would put her life in a danger. Meanwhile, her honesty was reflected on this incident:

Luckily, Patih Sidapaksa could do the mission and came back to the palace. Sadly he could not meet Sri Tanjung. The King lied. He said Sri Tanjung was in jail because she asked the King to marry her. The King said Sri Tanjung wanted to be a queen. At first Patih Sidapaksa believed the King. But Sri Tanjung then said.

"Throw me to the river. If the river smells good, it means I'm innocent. However, if the river smells bad, then the King is lying", said Sri Tanjung.(D9_LB)

This scene revealed how Sri Tanjung was very consistent on what was said and done, seen on how she sacrificed herself to show that she was right despite facing death.In regard to the portrayal of nature, this folktale described nature like a mother who taking care of her child wholeheartedly:

Patih Sidapaksa took the mission. When he arrived in the jungle, he saw a young deer. He pointed his arrow to the deer. Unfortunately, he missed the target. He ran after the deer. He was running and running until he arrived at a hut. Patih Sidapaksa knocked the door.A young and beautiful girl opened the door.(D10_LB)

The data above implicitly disclosed how nature, especially the forest ecosystem, cared for Sri Tanjung who lived in it all this time. Nature also guarded and defended Sri Tanjung when no one believed in her, just like how most mothers reacted when knowing her beloved child was being cornered:

\section{Sidapaksa then threw her into the river. Amazingly, the river smelled good.(D11_LB)}

The river which suddenly smelled fragrant after Sri Tanjung plunged in, indicatednature' great sense of caring for Sri Tanjung as a 'Mother Earth'. Since it could not express its affection in words, it showed it with symbols. 


\section{4) The Analysis of 'The Legend of Crying Stone'}

The plot of this tale was constructed with two female characters who were very opposite in personality:

On the way to the market, everybody admires the girl's beauty. They are also curious. Behind the beautiful girl, there is an old woman with a simple dress. The girl and her mother look very different!"Hello, pretty lady. Who is the woman behind you?" asks them. "She is my servant," answers the girl.(D12_LCS)

The daughter was very rude and unwilling to acknowledge her mother. She was obviously ashamed of her mother's shabby and old condition. Contrarily, the old widow is a kind-hearted and patient woman, as reflected in the data below:

she asks her mother to walk behind her. She doesn't want to walk side by side with her mother.Although her mother is very sad, she agrees to walk behind herdaughter. (D13_LCS)

The mother is very sad, but she doesn't say anything. (D14_LCS)

She always attempted to be patient with her daughter's treatment. She never scolded her and chose to keep her disappointment inside her heart. Yet, at the end, she could not take it anymore, so she cursed her into a stone.

"Mother, please forgive me!" she cries and ask her mother to forgive her.But it's too late. Her whole body finally becomes a big stone. Until now people still can see tears falling down the stone.(D15_LCS)

This incident signified an intimate relationship between the old widow and nature, which thenlet her to curse her daughter to stone. Besides, this also implicitly told the reader that nature was not inanimate object. Rather, it lived around human and was able to communicate with humans.

\section{Discussions}

A. The Depiction of Women and Nature in the Four Selected Indonesian Folktales

In the four selected Indonesian folktales, women are placed as the most important characters where their actions to nature have become intriguing issues in the plots. The ending of those tales are also similar that all of the women characters have to deal with problems related to human's psyche and nature. This first sub-chapter, hence, offers vivid elucidation regarding the portrayal of women and nature in the stories.

The first tale comes from West Sumatra entitled Malin Kundang. Malin Kundang is the story about the son who did not want to acknowledge his poor mother after becoming rich. At the end of the story, Malin's mother cursed him into a stone due to her resentment toward Malin's treatment. There are three main characters in the story namely, Malin Kundang, her mother and his wife. Malin Kundang was used to be obedient and kind-hearted village guy. He gave his utmost love to his mother as he had 
no one but his mother. One day, he decided to go wander, seeking the prosperous life he had never felt before. His efforts bore fruit as he owned a huge ship and beautiful wife. When Malin Kundang went back to his village, his mother hugged him with teary eyes. She was touched because her beloved son finally came home. Sadly, Malin Kundang had turned into a boastful guy who refused to acknowledge his poor mother. He pushed her mother to the ground and asked her to not call him her son. Malin's mother kept trying to reach him, but she eventually stopped after Malin shouts, "Enough, old woman! I have never had a mother like you, a dirty and ugly peasant!" and orders the ship captain to sail.Seeing Malin's ship moving away from the shore, his mother burst in tears while Malin were grinning hatefully from the boat. Malin's mother strongly felt hurt because her one and only son no longer admit her as his mother. Enraged, she then cursed Malin and turned him into a stone. In the calm sea, suddenly a storm came. His big ship sank and it was too late for Malin Kundang to apologize.

Concerning the figure of the mother, Malin Kundang folklore describes Malin's mother as a person full of love, especially in caring for and raising her son.Besides, her blessing for Malin to go wander, making his dreams come true and improving their lives, also showed her affection toward him. So, it was her love for Malin that caused her to persist in waiting for Malin's recognition that she was his real mother. She did not immediately get angry with her son's treatment, but she waited for her son to realize his mistake before it was too late. The tale also shows how mother has great dominance both in her child's life and in nature around her. Her great power over his son's fate was portrayed through her spiritual connection with God, since her prayers for Malin's success came true. Meanwhile, her connection with nature was illustrated by her power to curse her child to stone.

A sudden storm in the sea and darkness in sky when Malin's mother cursed him was also a symbol of women's attachment to nature. That is, nature really understands women's feelings, and it is also a land of life that must be respected, just like Mother. When human beings do not do a good deed to earth, disaster will come and nature will take everything back to her. This is to say that the mother is actually the earth itself.

The second folktale, Legenda Danau Toba, tells about the creation of Lake Toba in North Sumatera. The main characters in this story are Mr. Toba, Mr. Toba's wife, and their son, Samosir. Mr. Toba's wife was actually the incarnation of the fish that he caught in the river. It symbolizes the gift of Mother Earth to him, as the result of his struggle to cultivate the nature. Mr. Toba was responsible of taking care the woman and they got married not long after. Yet, the woman gave one condition to Mr. Toba that he should not tell their son about her origin. With the companion of the woman, Mr. Toba's life became more prosperous. He did not need to bother looking for sustenance. Everything was fine until one day Mr. Toba got angry with his son and shouted, "Your manner is like a little animal. It is because your mother spoiled you. You are so naughty. Well, it is because your mother is a fish. So you are like her. Go away from here". Shocked, Samosirran to his mother and told her what his father said. The woman felt sad and asked his son to escape to a hill. Shortly after that, heavy rain fell and all places covered with water. Mr. Toba died, Samosir survived on the hill (now called Samosir hill), while the woman turned back into fish.

This folklore depicts woman as beautiful, decisive, affectionate, and skilled at doing household chores such as cooking, washing, gardening, and cleaning the house. This is very much in line with the patriarchal view that strongly held in the past, where women were considered passive, obedient, and not prominent compared to men who were 
involved much in society. The woman is also depicted as being very dependent on men. Just like a fish that can never escape from water, when it incarnates, it turns into a woman who depends on men and nature to live. In addition, the story of Lake Toba perceives nature as something powerful that is enable to create and destroy human life. Living side by side with nature makes human's life easier because all their needs are provided by nature. Similarly, Mr. Toba's life became more prosperous when he was accompanied by his wife who is the incarnation of fish and the same time a symbol of nature. Nonetheless, if nature can be angry and cause disaster to destroy all life if human ignores or 'hurts' it. The ending of this story reminds us that what comes from the nature will go back to the nature, and if human cannot take care of nature, everything will be vanished.

The third tale is entitled The Legend of Banyuwangi. It tells the readers about the origin of the name of Banyuwangi city which is located in East Java. Banyuwangi alone literally means 'fragrant water' in Javanese language, so as to be expected, this tale had a lot to do with water as one of nature's elements. The story started with the journey of Patih Sidapaksa to hunt a young deer and unexpectedly got lost in the jungle. He found a small hut there and met Sri Tanjung, a beautiful girl living in the hut. They both fell in love and planned to get married after arrived in the village. However, their plan was ruined by the King who also fell in love with Sri Tanjung's beauty. It made the King gave Sidapaksa a difficult mission outside the village, so that he can propose Sri Tanjung. Due to her faithful promise to Sidapaksa, Sri Tanjung chose to refuse The King's proposal and as the result, she was jailed by the King. When Sidapaksa came back, The King lied to him and said that Sri Tanjung asked him to marry her. Sidapaksa believed what The King said, and Sri Tanjung told him "Throw me to the river. If the river smells good, it means I'm innocent. However if the river smells bad, then the King is lying." Realizing the fact that Sri Tanjung was honest, Sidapaksa cried, regretting what he had done to Sri Tanjung. However, Sri Tanjung was finally brought back to life by God because of her good characters.

In this story, Sri Tanjung is described as a woman full of honesty. She sticks to her conscience even though her honesty threatens her life. Besides, Sri Tanjung is a religious woman who carries out all the commandments of God. This religiousness that finally makes God bring her back to live with Sidapaksa. Concerning the portrayal of nature alone, the researchers find some kind of feminization here. Nature is represented as a mother who plays a lot in her child's life. This can be noticed in how Sri Tanjung lives and grows up in the middle of the forest since she was child. The forest ecosystem synergizes to fulfill her primary needs and to take care of her, just like a mother who wholeheartedly looks after her child. Nature also then brings her together with her soulmate, Sidapaksa. This resembles the life of Indonesian society in the past, where parents usually matched their daughter to a man they have chosen and deemed fit. Furthermore, Sri Tanjung's request for Sidapaksa to be dropped into the river symbolizes her desire to reunite with nature when she gets hurt.She is indeed no different from most women who choose to return to their parents, especially mother, when having problems. The river, which suddenly becomes fragrant after Sri Tanjung falls down, seems to indicate a mother who is defending her daughter who is being slandered. Since it cannot speak, it uses meaningful symbol to show that her daughter is innocent. This also somehow tells the readers about the strong bonding among nature and woman. 
The last folktale, The Legend of Crying Stone, is originated from Borneo. It is about a lazy young girl who did not like her mother. One day, they walk to the market to buy some stuffs and she asked her mother, the old widow, to walk behind her. The old widow was, of course, sad but she did what her daughter commanded. When people greeted them, the girl always said that the old widow was her servant. Long story short, the old widow could not hold the pain anymore. She asked God to punish her daughter, and it did happen. The girl's body slowly turned into stone. She cried and apologized to her mother, yet it was too late.

This tale obviously has two female characters with completely different dispositions. The girl is a lazy and spoiled one who never helps her mother to work or clean the house. She is also selfish because she wants all her requests to be granted regardless of her mother's poor condition. On the other hand, the old widow is a kind and patient woman. She still loves her daughter in spite of her harsh treatment. Never once does she repay her daughter's actions, even when she is mournful. Other than that, she is very religious as she always prays to God for encouragement. In general, The Legend of Crying Stone has similar plot with Malin Kundang where the mother is told to have intense connection with nature and is able to turn their children into nature-related stuff (stone). Moreover, nature is not only seen as an inanimate setting or object, but as a sacred place where a God or Spirit resides. It is also believed to be able to interact with humans, in a way that it grants the mother's request to punish her child.

All in all, these four folktales have similarities that it engages nature as the salient part which bring much influences to the plots. Barry (2009) categorizes the area of 'outdoor environments' within ecocriticism into the wilderness (e.g. desert, oceans, uninhabited continents); the scenic sublime (e.g. forests, lakes, mountains, cliffs, waterfalls); the countryside (e.g. hills, fields, woods); and the domestic picturesque (e.g. parks, gardens, lanes). Referring to this division, the focus of four selected folktales is on the second and third areas; wilderness and scenic sublime. To be more specific, The Legend of Lake Tobatakes river and lake as its setting; Malin Kundang takes place in the sea shore, The Legend of Banyuwangi mainly involves forest and river; and The Legend of Crying Stone happens in the forest. Profound involvement of nature in those folktales explicitly shows how nature and humans are closely related and influencing each other. Both nature and the life in it must be respected, hence mankind and nature have to follow universal symbiosis and ecological principles.

The folktales also depict nature as an entity which has an intimate connection with women, especially those who are oppressed. This is reflected in how nature helps Malin's mother and an old widow to punish their children; how it assists Sri Tanjung in revealing the real truth of her; and how it supports Mr. Toba's wife to let out her frustration at him. One of the most logical reasons why nature is associated with women is because of the strong patriarchal structure among society, where nature is regarded as something passive due to its role which is only to produce. Its passive role is linked to women who have less dominant role than men such as giving birth, doing household chores, providing food. As for the reason why nature is more siding with oppressed women is probably because the nature itself has experienced a lot of oppressions and exploitations, so it instinctively wants to help those who are oppressed too.

\section{B. The Role of Nature in Women's Self-Completion Process}

To figure out how nature plays a role in women characters' process of 
self-completion, the researchers analyze the selected folktales using psychological approach. It is done to provide readers with holistic comprehension of the tales, not only some parts of it, particularly related to the relation between nature and women. As explained previously, self-completion refers to the process of self-defining which involves the use of certain symbols (Wicklund\& Gollwitzer, 1981).

Everyone goes through a self-defining process that includes self-perceptions, feelings, beliefs, and values related to them (Atwater, 1995). It is generally formed through acquired experiences and interaction with the environment, thus it is not an innate factor. Fitts (1971) implies that self-concept has a forceful influence on a person's behavior, which is normally related his ideas about himself. If someone perceives himself as a powerful person, even though this may not be necessarily true, his behavior will usually display related concept. Strictly speaking, certain labels and symbols are utilized by individual to describe himself and build his identity in self-completion process.

In the folktales analyzed, researchers notice on how Malin's mother and the old widow define themselves as tough women. Malin's mother had been firmly taking care of Malin Kundang alone since her husband left. She also toughly gave up her only son to go wander which automatically made her live alone. The self-concept of Malin's mother as a strong person seems to be formed from her bitter life experiences, starting from living in poverty to being abandoned by her husband. As she felt that she could go through everything well, she regards herself as a strong woman. This is similar with what old widow experienced in the folktale 'The Legend of Crying Stones'. She raised her abusive child without the assistance of her husband and abundant wealth. All of her life experiences affect her to perceive herself as a strong woman who could endure any situation. Supporting this, Fitts (1971) argues that self-concept is influenced by several factors, one of which is experiences that can generate positive and valuable feelings.

Apart from their daily actions, it is evident that Malin's mother and the old widow involve nature in their process of showing their identity. When punishing Malin and the spoiled girl, the two mothers actually had many choices about what to change their children into. Yet, they chose to turn their child to stone, which is one of nature's elements. The stone itself is a symbol of hardiness, stability, and perpetuity. It personifies "the ability to be grounded and connected with the earth. .. [It also] allows us to feel the energy of the earth and teach us powerful lessons about endurance "(Morley, 2019, p.1). Referring to this statement, we can comprehend their preference on stone, that is to exhibit their strength and connectivity with earth and nature. They also want others to acknowledge their endurance in their difficult lives.

On the other side, woman in the legend of Lake Toba conceptualizes herself as a consistent person. When Mr. Toba broke his promise by revealing her origin to Samosir, the woman really gave him the consequences and decided to turn herself into a fish again. The researchers consider this action as a mechanism of defending her ego. Bowins (2004) defines self-defense mechanism as a psychological strategy used by a person to maintain his self-image. This mechanism arises either from conscious mindor unconscious mind, when a person tries to protect his ego, self, or mind from anxiety triggered by an unpleasant social reaction. Freud divides self-defense mechanism into several forms, including regression, which is carried out by Mr. Toba's wife. Regression is a condition where a person returns to an earlier level in an adaptation. With this setback, the individual can escape from unpleasant situation and return to a previous 
time where he feels loved and secured (McLeod, 2019). The way the woman changed her body back into a fish was actually a setback done to protect her ego. It is included as a setback because she had indeed been refined to become creature completed with a common sense, but she chose to return to being an animal. However, this action also simultaneously makes us aware of how important nature is to the woman because she prefers to return to it and fully depends on it. Her regression somehow implies that living as a fish in the lake is more enjoyable than being human. In the end, her love for nature is what drives her to set nature a medium in showing her identity as a consistent person and maintaining her ego.

Lastly, the researchers analyzes the action of Sri Tanjung in the Legend of Banyuwangi who jumped into the river to prove her honesty. It certainly can be classified as a symbol used to disclose her identity, specifically when her ego is being threatened. Unlike Mr. Toba's wife who maintained her ego by returning to the good times of her life, Sri Tanjung prefers the negative mechanism of self-harm when surviving from unacceptable or negative impulse, that is asking to be dropped to the river. Self-harm such as cutting oneself, breaking bones, or suicide is usually done by someone to deal with emotional pain. There are many factors triggering self-harm, one of which is the tough life trials and difficulties in seeking help, as experienced by Sri Tanjung. For someone who feels neglected or unloved, feeling the pain of self-harm is a better choice than just feeling the emptiness in him (The Royal Australian \& New Zealand College of Psychiatrists, 2009). This is exactly what Sri Tanjung feels. For her, returning to nature is better than being slandered and suspected by Sidapaksa, even though she must die for it. She chooses nature, especially rivers, as a place to die because she feels only nature that could accept her wholeheartedly, live her life, and make her happy since she was a child. Also, by uniting herself with nature, she can show her true identity as a truly honest woman.

In relation to the previous related studies, what researchers found here is in line with the results of Banti's analysis (2018) on the Mermaid movie. He figures out that Mermaid movie considers women as oppressed figures who fall into male's authority, similar with what Malin's mother, Mr. Toba's wife, and Sri Tanjung experienced. Moreover, Putri (2018) in her studies concerning the oppression of women characters in some Indonesian folktales reveals that most women in Indonesian folktales are described as beautiful and charming so that men are easily attracted. This resembles the depiction of Sri Tanjung and Mr. Toba's wife of which beauty captivates anyone who stares. Women on those folktales are also considered helpless, passive and submissive, similar to the women characters scrutinized in this study. The only difference is that thewomen characters hereare ultimately able to fight the oppression they experience, which is by involving nature to take revenge on those who abuse them and to show their identity as strong, unbeatable people. Regarding the portrayal of nature, Banti (2018) asserts that Mermaid movie raises many environmental problems caused by humans in its plot, such as the use of sonar transmissions that destroys the sea. The dialogues among characters also hint at the sea creatures' anxiety of the hands of these humans. The movie, hence, sees nature as passive and helpless against the oppression. On the other hand, nature in this study is regarded as a pro-women and very strong entity. It can punish those who oppress women and protect those who are oppressed. 


\section{Conclusion}

The fact that human cannot live without the nature around them has led to the emergence of ecocriticism as a study of literature and environment from an interdisciplinary perspective.One branch of ecocriticism, eco-feminist, examines the relationship between nature and women in literary works. In the Indonesian folktales analyzed by the researchers, nature is not merely a background, but it has a big role in the continuity of the story. It is represented to have close relation with humans, so that it may affect one another. Those folktales, nonetheless, seems to be more inclined towards oppressed women. This may be because nature alone has experienced a lot of oppressions, just like the women in the story.

To enrich the discussion, the researchers also examine the relationship between women's actions in those stories and their self-completion process using a psychoanalytic lens. The results indicate that they used nature to convey their self-concept as strong, consistent, and honest women. While their preference to choose nature as the medium may be based on their closeness with nature.

Finally, this paper suggests further researchers of ecocriticism to focus more on the other literary aspect of Indonesian literature, such as the mantra, song, and lyrics. This research can be employed through the interviews and observation with the ecological author and other stakeholders, like those working in the royal palace. Therefore, holistic understanding toward nature depicted in early Indonesian literature can be achieved.

\section{Acknowledgement}

We thank Lembaga Penelitian Pengabdian Masyarakat (LPPM) Universitas Pelita Harapan for fully supporting this research until it is published.

\section{References}

Atwater, E. (1995). Psychology of Living: Adjustment, Growth, and Behavior Today. New Delhi: Prentice Hall Pvt. Ltd.

Barry, P. (2009). Beginning Theory: An Introduction to Literature and Cultural Theory. Manchester: Manchester University Press.

Bowins, B. (2004). Psychological Defense Mechanisms: A New Perspective. The American Journal of Psychoanalysis, 64(1), pp. 1-26.

Bruner, J.S. (1991). The Narrative Construction of Reality. Critical Inquirt 18(1), pp.1-21. Retrieved from http://www.jstor.org/stable/1343711.

Clark, T. (2010). The Cambridge Introduction to Literature and the Environment. Cambridge: Cambridge University Press.

Dewi, N. (2016). Of People and Nature: Eco Education in Young Adult Literature from Asia, Proceeding of the $4^{\text {th }}$ Literary Studies Conference 2016, 254-259

Finzer, E. (2005). Mother Earth, Earth Mother: Gabriela Mistral as an Early Ecofeminist,. Retrieved November 7th, 2020 from http://www.jstor.org/stable/24368285

Fitts, W.H. (1971). The Self Concept and Self Actualization (1 st ed). Los Angeles: Western Psychological Services.

Glotfelty, C. (1994). What is Ecocriticism?.Retrieved November 6th, 2020 from 
www.asle.org/wp-content/uploads/ASLE Primer DefiningEcocrit.pdf

Harmon-Jones, C., Schmeichel, B.J., \& Harmon-Jones, E. (2009). Symbolic Self-completion in Academia: Evidence from Department Web Pages and Email Signature Files. European Journal of Social Psychology, 39, pp. 311-316.

Mambrol, N. (2017). Ecocriticism: An Essay. Retrieved November 6th, 2020 from https://literariness.org/2016/11/27/ecocriticism/

Mawere, M., Mubaya, T.R., Reisen, M.V., Stam, G.V. n.d. (2019) Maslow's Theory of Human Motivation and its Deep Roots in Individualism: Interrogating Maslow's Applicability in Africa. RetrivedNovember 7th, from https://www.researchgate.net/publication/302516151 Maslow's Theory of $\mathrm{H}$ uman Motivation and its Deep Roots in Individualism Interrogating Maslow' s Applicability in Africa

McLeod, S. (2019). Defense Mechanism. Retrieved November 8th, 2020 from https://www.simplypsychology.org/defense-mechanisms.html\#: :text=Regres sion,when $\% 20$ the $\% 20$ person $\% 20$ felt $\% 20$ safer.

Morley, K. (2019). Symbolism of Stones and Meanings. Retrieved November 7th, 2020 from

https://www.sunsigns.org/stones-meanings-symbolism/\#: : :text=The\%20sym bolism \%20of\%20stones \%20centers, $\% 2 \mathrm{C} \% 20$ versatile $\% 2 \mathrm{C} \% 20$ and $\% 20$ easily \%20accessible

Nassaji, H. (2015). Qualitative and Descriptive Research: Data Type Versus Data Analysis. Language Teaching Research, 19(2), pp. 129-132.

Putri, C.A. (2018). The Opression of Women Characters in Selected Indonesian Folklore. Paper presented at The 6th Literary Studies Conference: Re-imagining Difference and Extremism: Regional and Global Perspective, Yogyakarta, 11-12 October 2018, pp. 158-162.

Sandilands, C. (1997). Mother Earth, the Cyborg, and the Queer: Ecofeminism and (More) Questions of Identity. NWSA Journal 9.3, pp. 18-40.

Subanti, G. (2018). 'Locating the Human and Environmental Conflict in the Mermaid Using the Perspective of Feminism and Ecocriticism'. Paper presented at The 6th Literary Studies Conference: Re-imagining Difference and Extremism: Regional and Global Perspective, Yogyakarta, 11-12 October 2018, pp. 158-162.

Taflinger, R.F. (1996). Taking advantage; The Sociological Basis of Greed. Retrieved November 5th, 2020 from https://public.wsu.edu/ taflinge/socgreed.html

Ulrich, R.S.(1993_, 'Biophilia, biophobia, and natural landscapes', in S.R. Kellert and E.O. Wilson (eds.), The Biophilia Hypothesis (Island Press, Washington DC), pp. 73-137.

The Royal Australian \& New Zealand College of Psychiatrists. (2009). Self-Harm. Melbourne: Australia.

Wicklund, R.A. \& Gollwitzer, P.M. (1981). Symbolic Self-Completion, Attempted Influence, and Self-Deprecation. Basic and Applied Social Psychology, 2(2), pp. 89-114.

Wilson, E.O. (1984). Biophilia. Massachusetts: Harvard University Press. 
IDEAS, Vol. 8, No. 2, December 2020

ISSN 2338-4778 (Print) ISSN 2548-4192 (Online)

Yusuf, F., \& Susilo, M. (2020). Existentialist Feminism of Woman's Struggle in Cigarette Girl Novel. IDEAS: Journal on English Language Teaching and Learning, Linguistics and Literature, 8(1). doi:https://doi.org/10.24256/ideas.v8i1.1275

Zein, L.F. \& Setiawan, A.R. (2017). General Overview of Ecofeminism. Retrieved from https://www.researchgate.net/publication/335441481 General Overview of Ecofeminism 